\title{
CORROSION AND MECHANICAL PROPERTIES AND MICROSTRUCTURE OF CEMENT MORTAR CONTAINING CALCIUM SULPHATE WASTE
}

\author{
JULIETA DANIELA CHELARUa ${ }^{\text {, FIRUTA GOGA }}{ }^{\text {a* }}$, MARIA GOREA ${ }^{a}$
}

\begin{abstract}
The study presents the preliminary research on possibility to use the calcium sulphate waste (CSW) as replacing of sand in the cement mortar. The waste was chemically and mineralogical characterized. Four compositions of mortar without and with $7.5 \%, 18.78 \%$ and $37.50 \%$ waste were prepared. The X-ray powder diffraction evidenced the main mineral compounds in mortar as hydration products of calcium silicates (CSH) with a low index of crystallinity and different oxide ratio $\mathrm{CaO}: \mathrm{SiO}_{2}: \mathrm{H}_{2} \mathrm{O}$, quartz, calcite, anhidrite and gypsum. Optical microscopy reveals that the samples contains aggregates as quartz, muscovite and rocks, especially of metamorphic origin (quartzite, micaschists, and quartzitic schists) embedded in a fine matrix resulted by hydration reactions of cement compounds or reactions of waste components with other compounds from system. The corrosion properties of mortar, at different $\mathbf{C S W}$ concentrations, on rebar, were investigated by polarization measurements and electrochemical impedance spectroscopy. The results revealed that at $7.5 \%$ addition of waste anticorrosion properties are improved. As expected, the mechanical resistances (compressive and flexural strenght) decrease with increasing of waste in mortar composition.
\end{abstract}

Keywords: waste materials, corrosion, reinforced mortar steel, electrochemical techniques, mechanical properties

\section{INTRODUCTION}

In last years, the increasing quantities of waste materials has required finding of practical solutions for their recycling. There are many studies focused on using different wastes in oxide materials compositions,

\footnotetext{
a Department of Chemical Engineering, "Babes-Bolyai" University, 11 Arany Janos St., 400028 Cluj-Napoca, Romania

*Corresponding author: firutagoga@yahoo.com
} 
especially in cement concrete. In these cases, the wastes can replace the sand or aggregates in different proportions. This fact involves the reducing of energy and natural resources and obtaining of low cost final products.

In this way, there are studies on the mechanical properties or the corrosion properties of the concrete made with steel slag furnace [1], fly-ash [2, 3], plastics, crushed seashells [4], lime rich sludge, fine kaolinite sand [5], waste glass [3,6], glass and polypropylene fibers [7]. Many studies conducted in order to examine the possibility of using plastic and glass powders in civil engineering and construction were reported [8]. The use of glass waste in road construction, asphalt and others building materials was experimented [9]. A lot of researches are focused on using agriculture wastes in concrete compositions. For examples in [10] the durability properties of sustainable concrete incorporating high volume of palm oil waste were investigated.

On the other hand a major importance is accorded to the corrosion process in reinforced concrete, especially because its early identification is difficult. Many researches are focused on techniques for evaluation of the corrosion process in reinforced concrete mostly electrochemical techniques [11 - 13].

In this context, this paper reports the corrosion and mechanical properties correlated with chemical and mineralogical composition of waste and cement mortar which contain different percentage of calcium sulphate waste (CSW). The corrosion properties were studied in normal atmospheric conditions on steel embedded in mortar mixtures using electrochemical techniques (potentiodynamic polarization measurements and electrochemical impedance spectroscopy).

\section{RESULTS AND DISCUSSION}

\section{Characterization of raw materials}

In the experiments for obtaining the mortar cement mixtures the usual EN 197-1- CEM II/A-LL 42,5 R Portland cement was used. The usual sand and the calcium sulphate waste were incorporated as mortar aggregates. The calcium sulphate waste is resulted by thermal treatment at $600{ }^{\circ} \mathrm{C}$ of a mixture of $50 \%$ sand, $25 \%$ fired clay and $25 \%$ gypsum during the casting process of the art statues.

\section{Chemical composition of aggregates}

The chemical composition of sand and waste obtained by traditional wet chemistry analyses are presented in Table 1. 
Table 1. Chemical composition of sand and calcium sulphate waste

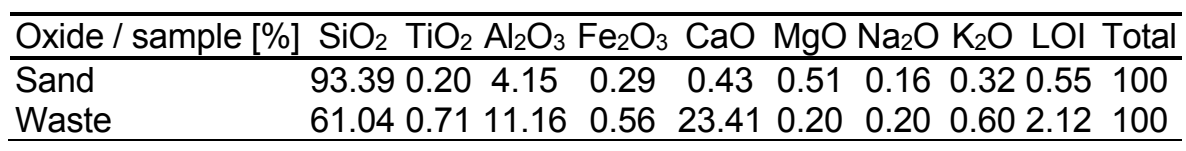

The usually sand for mortar contains a high amount of silicon oxides besides of small quantities of aluminum oxide respectively earth and alkaline oxides.

The calcium sulphate waste is mainly composed of silicon dioxide and aluminum oxide from sand and fired clay and calcium oxide from gypsum. The minor oxides are originating from impurities presented in clay.

\section{Mineralogical composition of calcium sulphate waste}

The mineral compounds of waste influence the hydration reactions of the cement components and/or react with other oxides from mixture forming new reaction products. The resulting compounds can be an inert/reactive material, a material with/without hydraulic properties and can alter the final characteristics of cement mortar. The mineralogical composition of the waste used in experiments was investigated by X-ray powder diffraction and the pattern is illustrated in Figure 1.

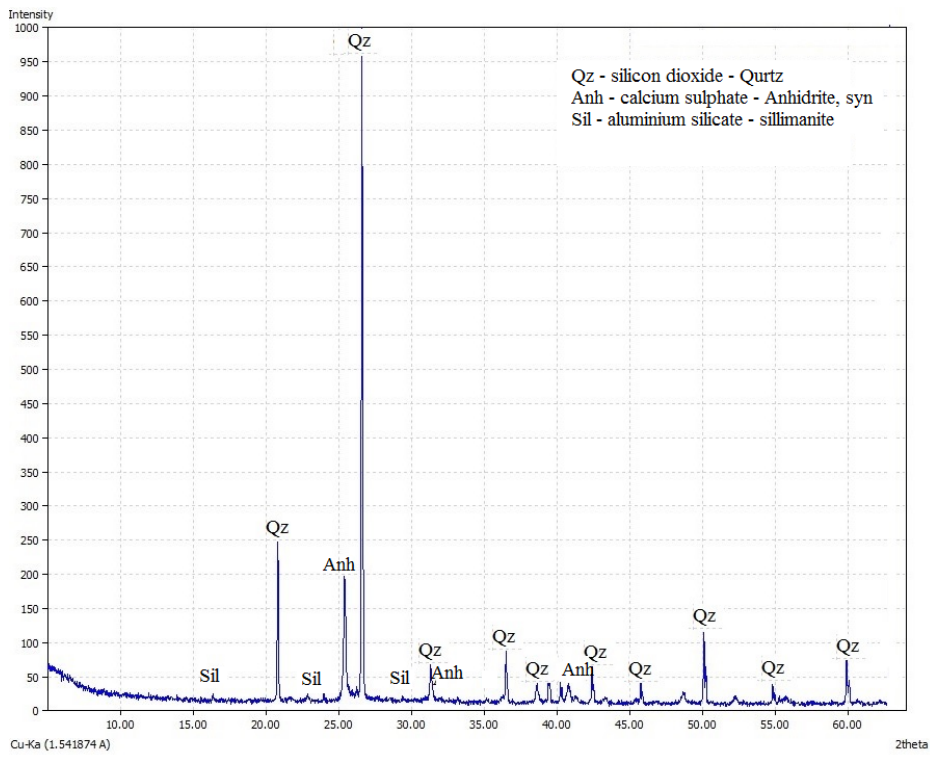

Figure 1. X-ray powder diffraction pattern of calcium sulphate waste. Qz quartz, Anh - anhydrite, Sil - silimanite. 
The X-ray powder diffraction evidence the main mineral compounds in calcium sulphate waste as quartz, calcium sulphate anhydrous, and silimanite.

\section{Characterization of mortar samples}

\section{Investigation of the corrosion process in reinforced mortar}

Potentiodynamic polarization measurements

Before the corrosion tests, the samples were cured for 30 days in humidity conditions. In order to evaluate behaviour of rebar in mortar with different CSW concentrations, the experiments were started with the open circuit potential (OCP) measurements for a period of 1 hour.
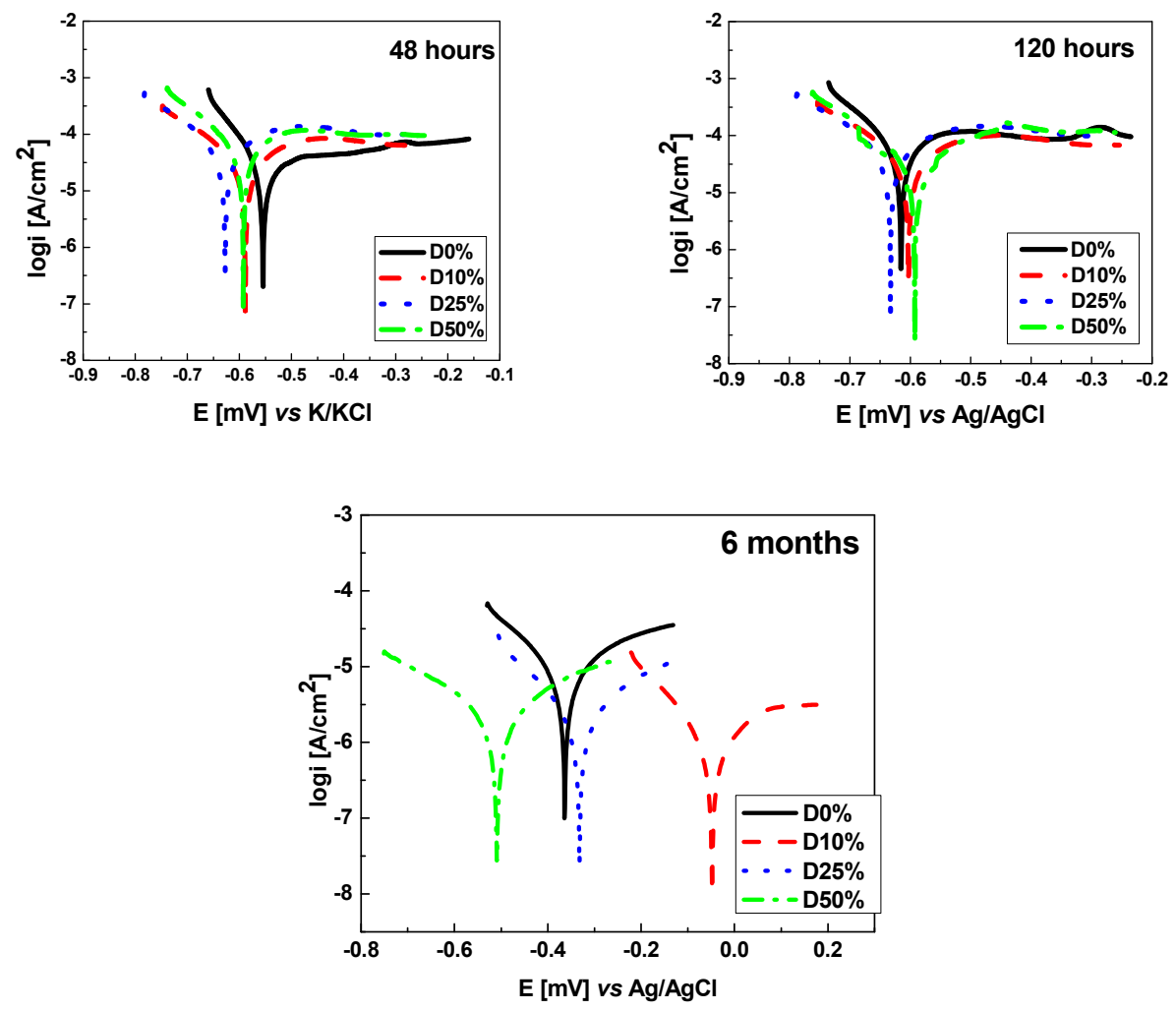

Figure 2. Polarization curves ( $\pm 200 \mathrm{mV}$ vs. ocp) for the studied samples at different concentrations of $\mathbf{C S W}$, potential scan rate, $10 \mathrm{mV} / \mathrm{min}$. 
In order to determine the corrosion process parameters (icorr - corrosion current density, $\mathrm{E}_{\text {corr }}$ - potential corrosion) polarization curves in the potential range of $\pm 200 \mathrm{mV}$ vs. OCP were realised (Figure 2).

To determine the polarization resistance values, the linear polarization curves were recorded, in the potential domain of $\pm 20 \mathrm{mV} v s$. OCP. The results obtained by Tafel interpretation and the polarization resistance values $\left(R_{p}\right)$, calculated as the inverse of the slope of each curve in case of all CSW concentrations, are shown in Table 2.

Table 2. Corrosion process parameters for the experimented samples

\begin{tabular}{ccccc}
\hline & Time & $\begin{array}{c}i_{\text {corr }} \\
{\left[\mu \mathrm{A} / \mathrm{cm}^{2}\right]}\end{array}$ & $\begin{array}{c}E_{\text {corr }} \\
{[\mathrm{mV} \text { vs K/KCl] }}\end{array}$ & $\begin{array}{c}R_{p} \\
{\left[\mathrm{k} \Omega \mathrm{cm}^{2}\right]}\end{array}$ \\
\hline \multirow{3}{*}{$\mathbf{D}_{\mathbf{0}}$} & $48[\mathrm{~h}]$ & 0.288 & -554 & 0.79 \\
& $120[\mathrm{~h}]$ & 0.526 & -615 & 0.50 \\
& 6 months & 7.924 & -364 & 3.23 \\
\hline \multirow{3}{*}{$\mathbf{D}_{10}$} & $48[\mathrm{~h}]$ & 0,309 & -589 & 1.56 \\
& $120[\mathrm{~h}]$ & 0,371 & -605 & 0.87 \\
& 6 months & 1.315 & -43 & 33.64 \\
\hline \multirow{3}{*}{$\mathbf{D}_{25}$} & $48[\mathrm{~h}]$ & 0,479 & 627 & 0.52 \\
& $120[\mathrm{~h}]$ & 0,304 & -633 & 0.48 \\
& 6 months & 2.082 & -502 & 12.53 \\
\hline \multirow{3}{*}{$\mathbf{D}_{50}$} & $48[\mathrm{~h}]$ & 0,493 & -595 & 0.52 \\
& $120[\mathrm{~h}]$ & 0,275 & -585 & 0.51 \\
& 6 months & 1.891 & -508 & 15.83 \\
\hline
\end{tabular}

Analyzing the Table 2 data, it can observe that in the first two cases there are no visible differences between samples without and with different percentage of CSW. In case of corrosions tests after 6 months, it can see an increase of the corrosion current density values for all investigated samples. Though, it can observe that the best result was noticed at $7.5 \%$ CSW. This fact is suggested by the high value of the polarization resistance $\left(R_{p}=33.64\right.$ $\left.\left[\mathrm{k} \Omega \mathrm{cm}^{2}\right]\right)$ and the low value of the corrosion current density $\left(\mathrm{i}_{\text {corr }}=\mathbf{1 . 3 1 5}\right.$ $\left.\left[\mu \mathrm{A} / \mathrm{cm}^{2}\right]\right)$. Probably a small amount of $\operatorname{CSW}(7.5 \%)$ in the mortar composition leads to the formation of a protective layer on the rebar.

Electrochemical impedance spectroscopy

The Nyquist diagrams obtained for the all samples, after 6 months (the samples were maintained in this time in humidity conditions) are presented in Figure 3b. 

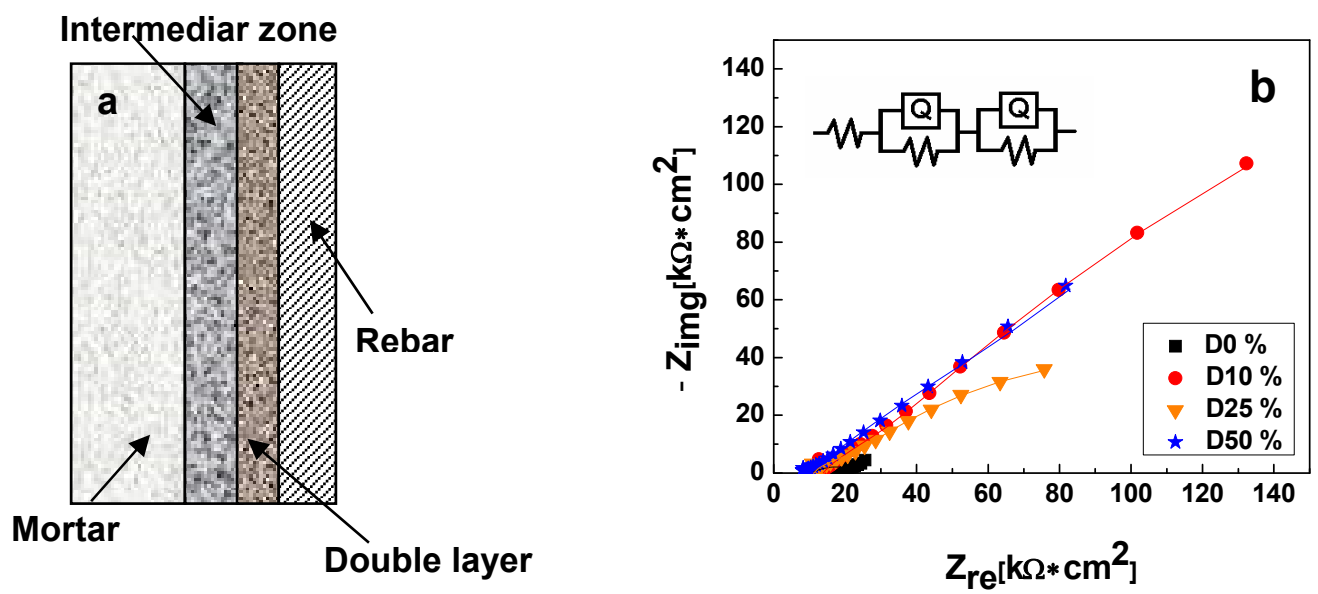

Figure 3. a) Schematic representation of the mortar / rebar interface; b) Nyquist impedance diagrams of samples with $0 \%, 7.5 \%, 18.78 \%$, respectivelly $37.50 \%$ CSW; the lines represent fitted data.

Table 3. Electrochemical parameters for studied samples

\begin{tabular}{crrrrrrrr}
\hline $\begin{array}{c}C \\
{[\mathrm{mM}]}\end{array}$ & $\begin{array}{c}R_{m} \\
{\left[\mathrm{k} \Omega \mathrm{cm}^{2}\right]}\end{array}$ & $n_{f}$ & $\begin{array}{c}R_{f} \\
{\left[\mathrm{k} \Omega \mathrm{cm}^{2}\right]}\end{array}$ & $\begin{array}{c}C_{f} \\
{\left[\mu \mathrm{F} / \mathrm{cm}^{2}\right]}\end{array}$ & $n_{d}$ & $\begin{array}{c}R_{t} \\
{\left[\mathrm{k} \Omega \mathrm{cm}^{2}\right]}\end{array}$ & $\begin{array}{c}C_{d} \\
{\left[\mu \mathrm{F} / \mathrm{cm}^{2}\right]}\end{array}$ & $\begin{array}{c}R_{p}{ }^{*} \\
{\left[\mathrm{k} \Omega \mathrm{cm}^{2}\right]}\end{array}$ \\
\hline $\mathbf{D}_{0}$ & 10.59 & 0.67 & 24.22 & 59.11 & 0.37 & 13.02 & 2.33 & 24.22 \\
$\mathbf{D}_{10}$ & 13.86 & 0.63 & 9.56 & 12.14 & 0.58 & 887.5 & 301 & 897.06 \\
$\mathbf{D}_{25}$ & 11.22 & 0.64 & 7.14 & 4.26 & 0.54 & 175.4 & 271.6 & 182.54 \\
$\mathbf{D}_{50}$ & 11.85 & 0.69 & 290 & 13.98 & 0.76 & 13.66 & 1.47 & 303.66 \\
\hline
\end{tabular}

$R_{p}{ }^{*}=R_{f}+R_{c t}$

A schematic representation of the rebar / mortar interface is shown in Figure 3a. The existence of the two zones, the intermediar zone, and the zone with charge transfer and the double layer capacitance at rebar interface are assumed. Based on these results for all samples the experimental impedance spectra were analyzed by fitting to a $R((Q R)(Q R))$ equivalent electrical circuit (Figure 3b). This circuit was used in many studies involving concrete corrosion [11-13].

The equivalent electrical circuit from Figure $3 b$ is composed of $R_{m}$ the mortar resistance, $Q_{f}$ - the constant phase element (CPE) of the film, $R_{f}$ the rust layer film, $Q_{d}$ - the constant phase element (CPE) of the electric double layer and $R_{t}$ - the charge transfer resistance at the rebar interface, $n_{d}$, $\mathrm{n}_{\mathrm{f}}$ - coefficients representing the depressed characteristic of the capacitive 
loops in the Nyquist diagram. Using the equation $C=\left(R^{1-n} Q\right)^{1 / n}$ the values of $\mathrm{C}_{\mathrm{d}}$ and $\mathrm{C}_{\mathrm{f}}$ were calculated. After the fitting experimental impedance spectra the results are presented in Table 3 . The quality of fitting procedure was evaluated by the chi squared $\left(X^{2}\right)$ values, which were of order $10^{-3}$.

In case of a redox process, the value of the polarization resistance $\left(R_{p}=R_{f}+R_{t}\right)$ can be correlated with the corrosion rate. Therefore analyzing the dates from Table 3 it can be seen that the polarization resistance is higher in case of $7.5 \% \operatorname{CSW}\left(\mathrm{R}_{\mathrm{p}}=897.06\left[\mathrm{k} \Omega \mathrm{cm}^{2}\right]\right)$ than the other samples. The results obtained from polarization curves are confirmed.

\section{Macroscopic aspect of the studied samples}

The all mortar samples were prepared and cured as a standard cement mortar. After 28 days, the samples were submitted to the corrosion investigation. The aspect of mortar samples with working electrodes after corrosion test is presented in Figure 4.

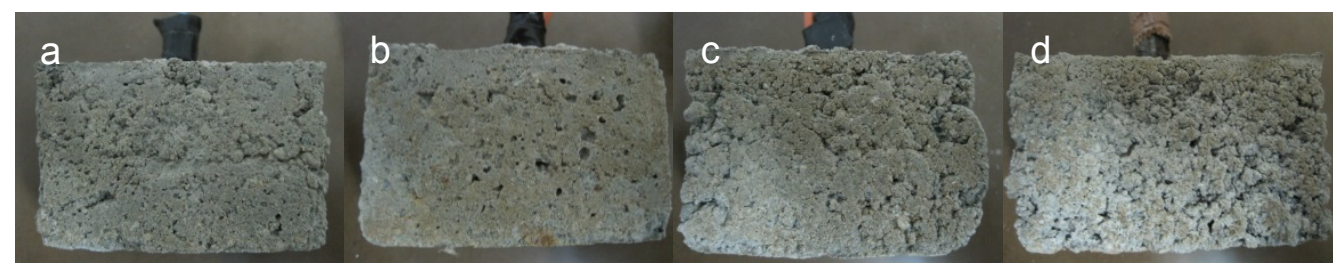

Figure 4. Aspect of samples with working electrodes (steel rebar) in mortar at different percentage of $\mathrm{CaSO}_{4}$ waste: a) $0 \%$, b) $7.5 \%$, c) $18.78 \%$, d) $37.50 \%$

The pores with different sizes and shape, rounded and elongated are observed. A light yellowish red shade appears on the surface of mortar samples is attributed to the iron oxides and hydroxides present in cement mortar composition. Moreover these oxi-hydroxides can migrated from the corrosion products layer formed on the steel rebar.

\section{Optical microscopy}

The optical microscopy in polarized light performed on thin section slices obtained from studied cement mortar allowed to identify and evidence some textural aspects of samples.

From structural point of view, the samples consist of relatively small aggregates (grain sizes ranged between 0-4 mm) embedded in a fine matrix resulted by hydration reactions of cement compounds or reactions of waste components with other compounds from system. 


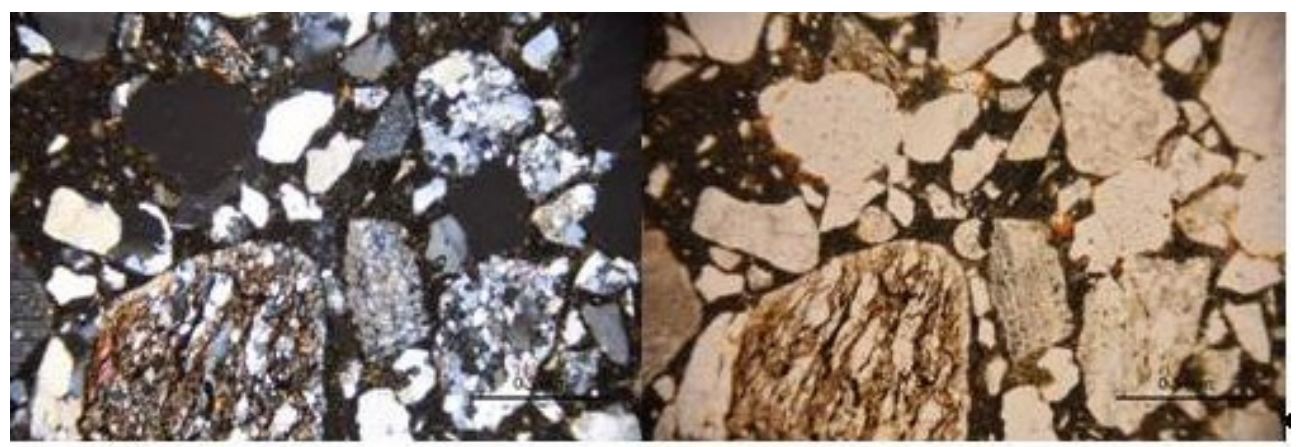

Figure 6. Textural aspects of D0 samples showing rounded aggregates consisting of quartz, muscovite, quartzite, micaschists into an isotropic matrix.

(Left $\mathrm{N}+$, right NII)

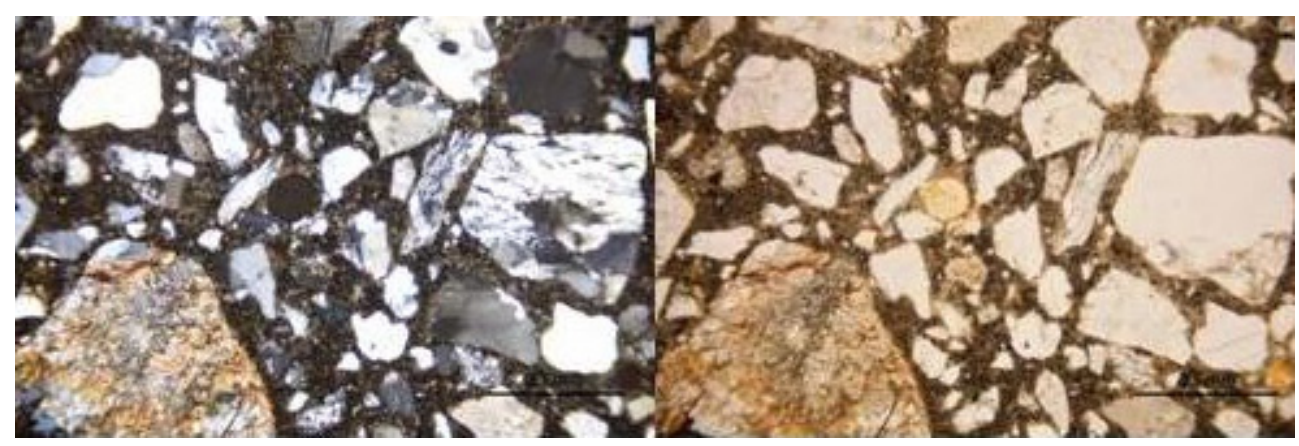

Figure 7. Textural aspects of D10 samples, showing a very fine crystallized matrix having rounded pores infilled with iron hydroxides.

(Left $\mathrm{N}+$, right NII)

The aggregates are mainly composed from sand with complex composition consisting of fragments of minerals (quartz, muscovite, etc.) and rocks, especially of metamorphic origin (quartzite, micaschists, and quarzitic schists) (Figures 6 - 9). Some fragments of rocks from aggregate (Figures $6,7)$ show different degree of feldspar transformation into clay minerals. As secondary minerals, iron hydroxides are also present.

Generally, the matrix is very fine grained and dominantly assists of calcium silicate hydrates, calcite, and iron hydroxides. Gypsum and anhydrite are very small in size and difficult to be identified into the thin section. In the matrix are also developed spherical pores, sometime infilled with iron hydroxides. 


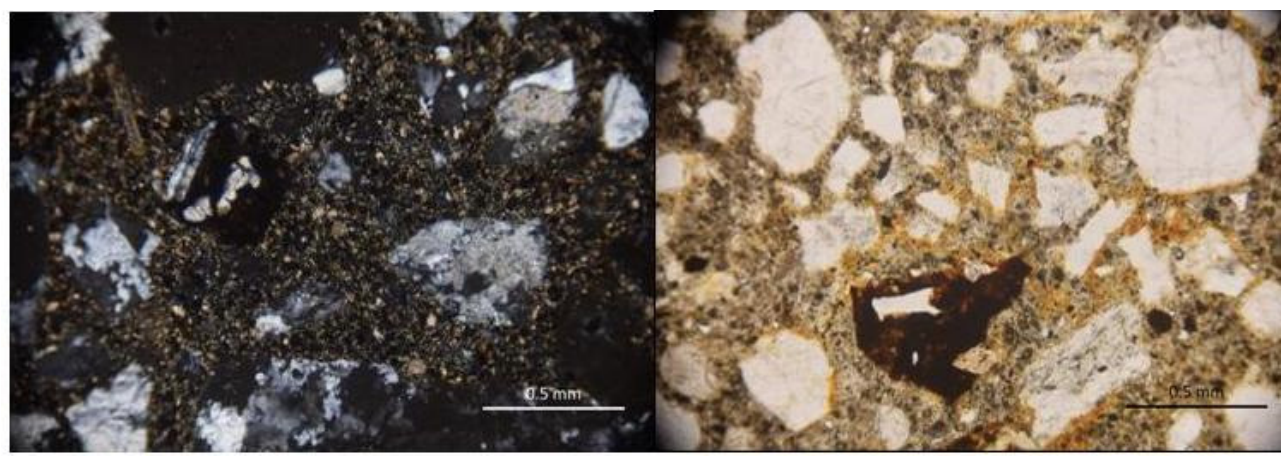

Figure 8. Textural aspects of D25 samples with fine calcite crystals in the matrix (left, $\mathrm{N}+$ ). Iron hydroxides as irregular grain as well as developed as thin rim on the surface of the aggregate (right NII)

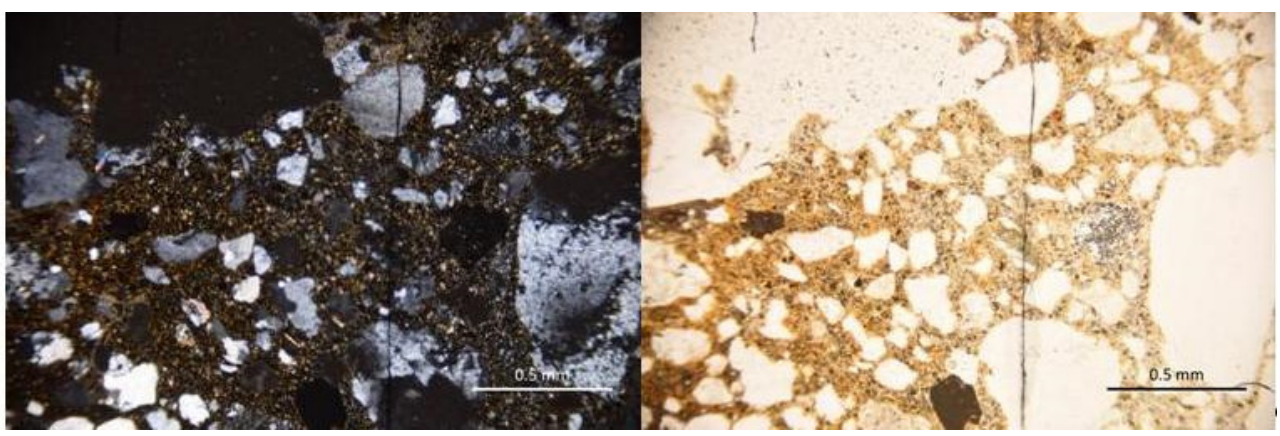

Figure 9. Textural aspect of D50 samples, with fine crystallized calcite in the matrix which is uniformly impregnated with iron hydroxides of brown color

(left $\mathrm{N}+$, right NII)

\section{Mineralogical composition of studied mortars}

X-ray powder diffraction patterns were realized on mixtures of cement mortar without and with calcium sulphate waste replacing the sand in various percent, conform to Table 4.

The samples tested of corrosion attack were milled till microns size of grains and the powders were investigated by X-ray powder diffraction. The XRPD patterns of the experimented samples are presented in Figure 5. 


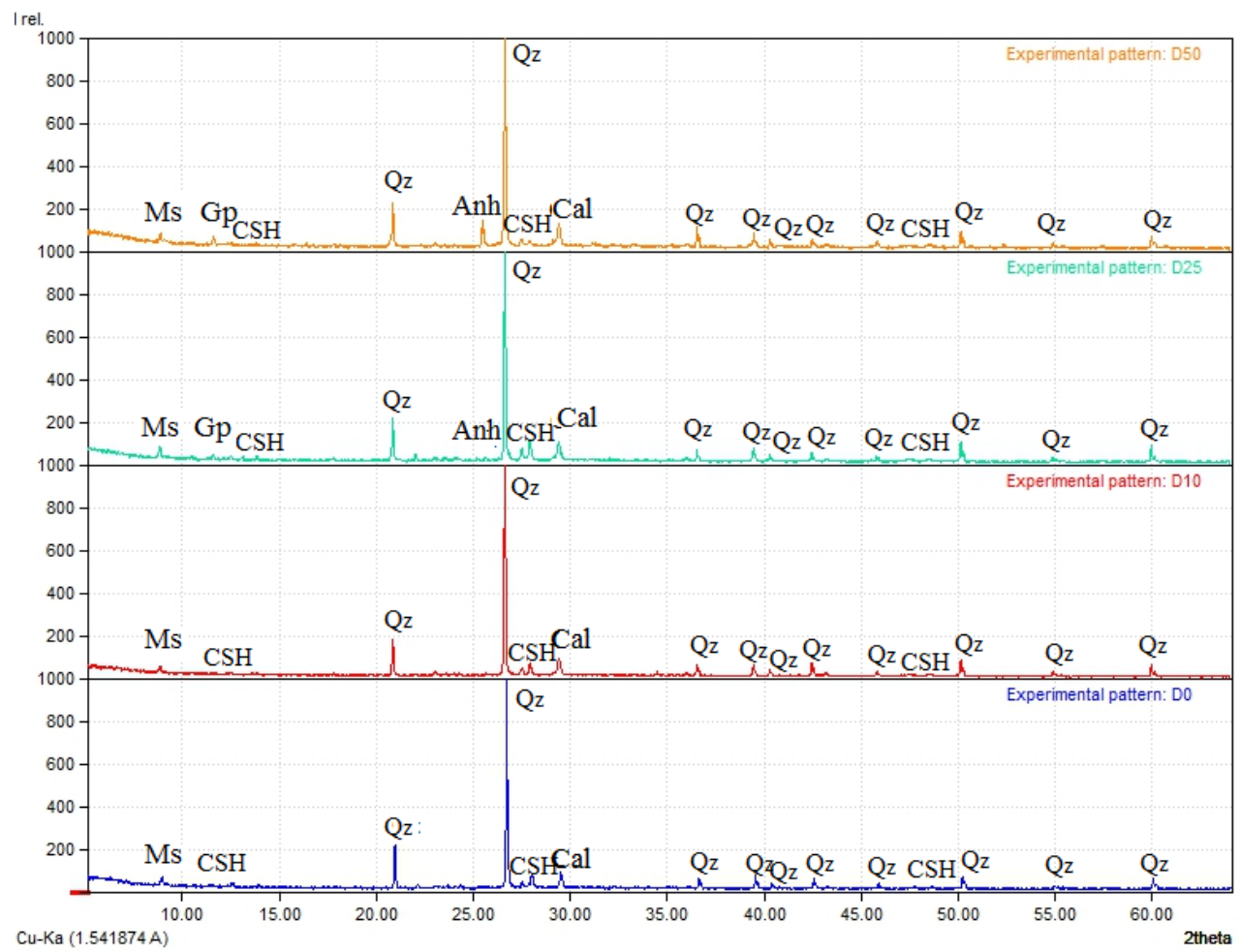

Figure 5. X-ray powder diffraction patterns of experimented samples. Qz - quartz, Anh - anhydrite, Ms - muscovite, Gp - gypsum, Cal - calcite, CSH - calcium silicate hydrate.

The X-ray powder diffraction reveals the mineral compounds in all experimented mortar samples. In the etalon sample D0 it was identified quartz and muscovite provided mainly from sand, calcite and hydration products of calcium silicates $(\mathrm{CSH})$ with a low index of crystallinity and different ratio $\mathrm{CaO}: \mathrm{SiO}_{2}: \mathrm{H}_{2} \mathrm{O}$. Calcium aluminates, calcium aluminoferrites and ettringite are in small quantities and difficult to be identified. In sample D25 and D50 with a high content of calcium sulphate waste the specific peaks of anhydrite and gypsum are present. These can explain due to the present of anhydrite in waste composition. During the curing and corrosion tests, in solution, the anhydrite is partially solubilized and the gypsum is formed. 


\section{The mechanical properties of experimented samples}

\section{Compressive strength of mortars}

The compressive strength of parallelepiped specimens $(40 \times 40 \times 160$ $\mathrm{mm}$ ) with different percent of calcium sulphate waste (CSW) was tested at 14, 28 and 90 days. The results are shown in Figure 10. It can see that the compressive strength as expected decreases with the increase of CSW at all term of testing. The lowest value of strength is obtained for sample D50. The closest value of resistance compared with the etalon is for D10 sample.

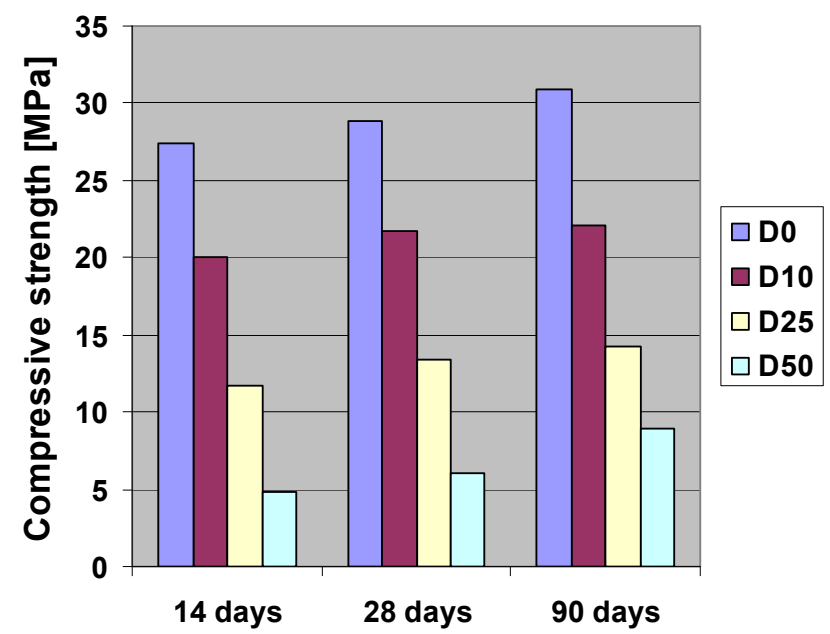

Figure 10. Compressive strength of the studied samples

\section{Flexural strength of mortars}

The flexural strength for all mortar compositions is shown in Figure 11. As expected, the values of the flexural strength have a similar behaviour as in compressive strenght case. The flexural strength values decrease with increasing of calcium sulphate waste content in mortar composition. The D10 composition can be considered appropiate for use in some applications (lower mechanical resistance but higher corossion resistance). 


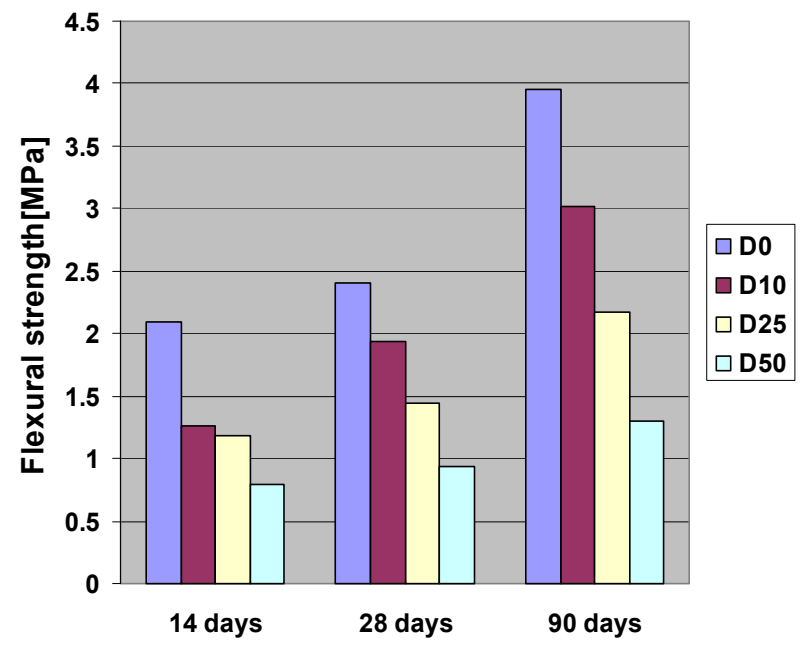

Figure 11. Flexural strength of the studied samples

\section{CONCLUSIONS}

In this study, waste materials provided from art manufacturing were used as an aggregate into cement mortar. The chemical composition of waste reveals a high content of $\mathrm{CaO}$ besides the $\mathrm{SiO}_{2}$ and $\mathrm{Al}_{2} \mathrm{O}_{3}$. The main mineral compounds evidenced by X-ray powder diffraction are quartz, calcium sulphate anhydrous, and silimanite. In the cement mortar, hydration products of calcium silicates $(\mathrm{CSH})$ with a low index of crystallinity and different oxide ratio $\mathrm{CaO}: \mathrm{SiO}_{2}: \mathrm{H}_{2} \mathrm{O}$ and calcite are identified. The anhidrite and gypsum resulted from anhidrite solubilization are present in higher quantities in D25 and D50 samples than D10. Their presence drastically decreases the mechanical resistance of these samples, more compressive strength. From textural point of view, the samples consist of aggregates with grain sizes ranged between 0-4 mm (quartz, muscovite) and rocks, especially of metamorphic origin (quartzite, micaschists, and quartzitic schists) embedded in a fine matrix resulted by hydration reactions of cement compounds or reactions of waste components with other compounds from system.

Based on the electrochemical investigations (polarization and impedance measurements) it can be concluded that, in case of addition $7.5 \% \mathrm{CSW}$ in the mortar composition, the anticorrosion properties are improved.

The corrosion behavior of the rebar in mortar can be simulated with a $\mathrm{R}((\mathrm{QR})(\mathrm{QR}))$ electric circuit. 


\section{EXPERIMENTAL}

The experimental mortar compositions contain as raw materials, cement, sand and calcium sulphate waste, table 4 . The cement proportion was maintained in all the tested compositions ( $25 \% \mathrm{wt})$. The D0 sample is the etalon mortar wich not contains waste and in the next three composition (D10, D25 and D50) a part of sand was replaced by calcium sulphate waste (7.5, 18.78 and $37.50 \% \mathrm{wt})$. As a result, the calcium sulphate in D10 composition is about $1.76 \%$, in D25 about $4.41 \%$ and in D50 about $8.83 \%$.

Table 4. Composition of studied samples

\begin{tabular}{cccc}
\hline Sample & $\begin{array}{c}\text { Cement } \\
{[\%]}\end{array}$ & $\begin{array}{c}\text { Sand } \\
{[\%]}\end{array}$ & Calcium sulphate waste [\%] \\
\hline $\mathbf{D}_{0}$ & 25 & 75 & - \\
$\mathbf{D}_{10}$ & 25 & 67.5 & 7.50 \\
$\mathbf{D}_{25}$ & 25 & 56.22 & 18.78 \\
$\mathbf{D}_{50}$ & 25 & 37.50 & 37.50 \\
\hline
\end{tabular}

The mortar samples were prepared in a laboratory cement mixer. The sand and waste in the quantity according to the recipe were added and homogenised $\sim 30$ seconds. Then the cement and water were added. The mixing continues for another 90 seconds. The mixer is stoped for 90 seconds and then it is restarted for 2 minutes. The final mixture is poured into metalic moulds $(40 \times 40 \times 1600 \mathrm{~mm})$ for mechanical tests. After $24 \mathrm{~h}$ the mortar samples are released from the moulds and preserved in wet environment at $20^{\circ} \mathrm{C}$ for 14 days, 28 days or 90 days.

The mechanical characteristics (compressive and flexural strength) are investigated after these intervals on hydraulic press CONTROLS 50C66V2 in accordance with romanian standard SR EN 196-1.

The electrochemical characterization was performed by a PC controlled electrochemical analyzer PAR 2273 (Princeton Applied Research, SUA) using an electrochemical cell (Figure 12) that contains three electrodes platinum counter electrode, a reference electrode a $\mathrm{K} / \mathrm{KCl}$ and as working electrode a steel rebar, with an exposed area of $9.30 \mathrm{~cm}^{2}$. For electrical contact, metal wires were attached.

The polarization curves were recorded in a potential range of \pm 20 $\mathrm{mV}$ (for $\mathrm{R}_{\mathrm{p}}$ determination) and of $\pm 200 \mathrm{mV} v \mathrm{~s}$. the value of the open circuit potential (for Tafel interpretation), with a scan rate of $10 \mathrm{mV} / \mathrm{min}$. OCP was measured during 1 hour. 
The impedance spectra were acquired in the frequency range $10 \mathrm{kHz}$ to $10 \mathrm{mHz}$ at 10 points / decade with an AC voltage amplitude of $\pm 10 \mathrm{mV}$, after the open circuit potential was carried out for 1 hour. The data were interpreted on the basis of equivalent electrical circuits, using the ZSimpWin V3.21 software for fitting the experimental data.

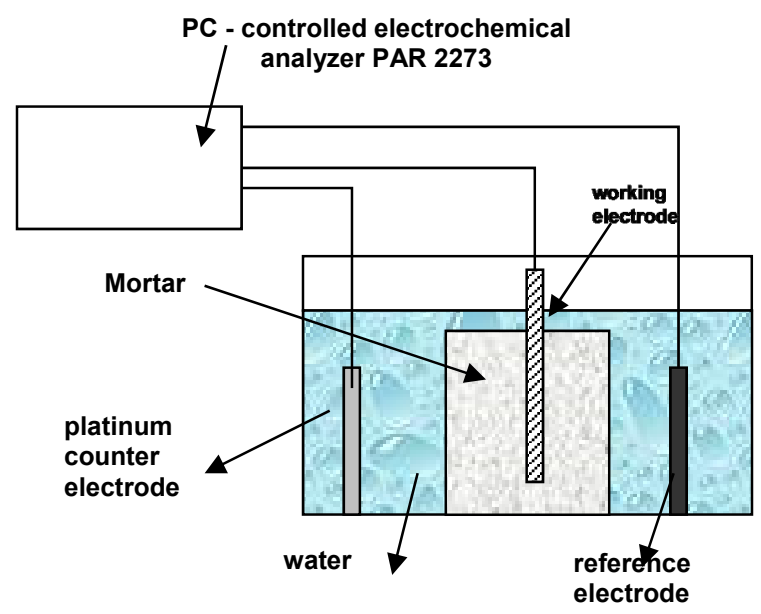

Figure 12. Electrochemical cell used for performing electrochemical measurements

Before of the electrochemical tests, the samples were maintained in water for 48 hours for the hydration of the mortar, in order to ensure conductivity between the working electrodes, reference electrode and counter electrode.

\section{REFERENCES}

1. S. Miyazawa, Cem. Soc. Concr. Technol., 2011, 64, 244-250.

2. E.J. Ruíz, J.R. Cortes, W.A. Aperador, International Journal of Chemical, Molecular, Nuclear, Materials and Metallurgical Engineering, 2015, Vol.9, No.3.

3. S.C. Kou, F. Xing, Advances in Materials Science and Engineering, Volume 2012, Article ID 263243, http://dx.doi.org/10.1155/2012/263243

4. D.H. Nguyen, M. Boutouil, N. Sebaibi, F. Baraud, L. Leleyter, Construction and Building Materials, 2017, 135, 137 - 150.

5. S.A. Abo-El-Enein, F.S. Hashem, M.S. Amin, D.M. Sayed, Construction and Building Materials, 2016, 126, 983 - 990. 
6. T.S. Serniabat, M.N.N. Khan, M.F.M. Zain, International Journal of Civil, Environmental, Structural, Construction and Architectural Engineering, 2014, Vol.8, No.10.

7. H. Fathi, T. Lameie, M. Maleki, R. Yazdani, Construction and Building Materials, 2017, 133, 443 - 449.

8. B. Chanbane, G.A. Sholar, J.A. Musselman, G.C. Page, Ten-year performance evaluation of asphalt-rubber surface mixes. Transportation Research Record No. 1681, Transportation Research, Washington, DC, 1999, pp. 10 - 18.

9. J., Rindl, Recycling Manager, report by Recycling manager, Dane Country, Department of Public Works, Madison, USA, 1998.

10. M.M. UI Islam, K.H. Mo, U.J. Alengaram, M.Z. Jumaat, Journal of Cleaner Production, 2016, 137, 167 - 177.

11. F. Cao, J. Wei, J. Dong, W. Ke, Corrosion Science, Article in press, doi.org/10.1016/j.corsci.2015.08.020.

12. D.V. Ribeiro, J.C.C. Abrantes, Construction and Building Materials, 2016, 111, $98-104$

13. N.M. Ahmed, M.G. Mohamed, M.R. Mabrouk, A.A. ELShami, Construction and Building Materials, 2015, 98, 388 - 396. 
